九州大学学術情報リポジトリ

Kyushu University Institutional Repository

\title{
On Some Cretaceous Corbulids from Japan
}

0ta, Yoshihisa

Fukuoka Gakugei University

https://doi.org/10.5109/1543616

出版情報：九州大學理學部紀要：Series D, Geology. 15 (1)，pp. 149-161，1964-06-25. Faculty of Science, Kyushu University バージョン:

権利関係: 
Mem. Fac. Sci., Kyushu Univ., Ser. D, Vol. XV, No. 1, pp. $149-161,5$ text-figs., plates $20-21$, May 31,1964

\title{
On Some Cretaceous Corbulids from Japan
}

\author{
$\mathrm{By}$ \\ Yoshihisa OTA
}

\begin{abstract}
s
Five species of the family Corbulidae are described from the Cretaceous formations of Kyushu and Chugoku. They are grouped in three new genera, Pulsidis, Eoursivivas and Nipponicorbula, in the subfamily Caryocorbulinae.
\end{abstract}

\section{Introduction}

So far as I know, few Corbulid pelecypods have been described from the Mesozoic deposits in Japan. Specimens of the Corbulidae, however, occur commonly in the Cretaceous deposits of Kyushu and western Chugoku. Through the study of them five species belonging to three new genera in the subfamily Caryocorbulinae have been distinguished. They are described below. The described specimens are preserved at the Fukuoka Gakugei University unless otherwise stated.

Before entering the description I wish to express my hearty thanks to Professor Tatsuro Matsumoto and Dr. Itaru HaYAmI of the Kyushu University and also Dr. Tadashige HABE of the National Science Museum for their kind guidance and encouragement throughout this work. Prof. T. Matsumoto, furthermore, critically read the typescript of this paper. Thanks are also due to Dr. Kametoshi KANMERA and Dr. Hakuyu OKADA of the same university for suggestions from their expert knowledge on the localities of Corbulid pelecypods.

This study was partly financed by the Grant in Aid for Scientific Researches from the Ministry of Education.

\section{Systematic Description}

Family Corbulidae

Subfamily Caryocorbulinae VoKes, 1945

Genus Pulsidis, nov.

Type-species.-Pulsidis nagatoensis, gen. et sp. nov. (to be described below), (from the Lower Neocomian, Yoshimo Formation in Yamaguchi Prefecture).

Manuscript received November 7, 1963. Communicated by Professor Tatsuro Matsumoto at whose suggestion this work has been undertaken as a part of the "Systematic studies of the Upper Mesozoic in Japan".

Yoshihisa OTA: Fukuoka Gakugei University; formerly a visiting fellow to the Department of Geology, Kyushu University. 
Generic diagnosis.-The shell is rather small, moderately inflated, and inequivalved. The right valve is larger than the left, rostrated with a low ridge extending from the umbo to the postero-ventral margin and provided with an additional shallow groove on both sides of the ridge. The left valve is subtrigonal, not so produced posteriorly as the right and provided with only a weak ridge extending from the umbo to the postero-ventral margin. The umbones are moderately inflated, prominent, and slightly prosogyrous, the right being slightly higher than the left. The surface of the valve is marked with low, fairly wide, top-flattened regular concentric ribs, which are separated by concentric narrow interspaces.

The interior of the right valve is grooved for the reception of the margins of the left. The right cardinal tooth is subtriangular, rounded on the ventral side, relatively large, and heavy; the resilial pit is prominent and elongate, and extends to the posterior side of the cardinal tooth. The left valve has a relatively broad chondrophore which is posteriorly almost continuous to the dorsal margin of the valve, although there is a shallow groove between them. A weak median groove appears on the dorsal side of the chondrophore and is gradually strengthened toward the posterior. The muscle scars are slightly thickened; the pallial line is moderately well impressed, forming a nearly right angle at the posteroventral corner, with slight sinuation.

Affinities.-In the hinge structure, this is somewhat similar to Caryocorbula GARDNER, 1926, and Panamicorbula PILSBRY, 1932. While those two genera have a bipartite chondrophore, this new genus has no median ridge on the chondrophore. Genus Corbula LAMARCK, 1799, as represented by the type-species, Corbula sulcatus of the living species, is apparently similar to this new genus in the outline of the shell and the concentric ribbing, but they differ in the hinge structure.

Pulsidis nagatoensis, sp. nov.

Pl. 20, figs. 1-14, 25; Text-fig. 1.

Material.-Holotype, GT. Y6301, a right inner mould (Pl. 20, fig. 1). Paratypes, GT. Y6322 and 6323, right inner moulds (Pl. 20, figs. 9, 5a, b) and GT. Y6314, a right external mould (Pl. 20, fig. 4); GT. Y6303 and 6305, left inner moulds (Pl. 20, fig. 7) and GT. Y6316, a left external mould (Pl. 20, fig. 14). All the above types were collected by me from the Yoshimo Formation on the coastal region of Yoshimo, Shimonoseki city, Yamaguchi Pref. Other comparable specimens were also obtained by me from the Kawaguchi Formation at Tanoura and Fukami in Kumamoto Prefecture.

Measurements.-

\begin{tabular}{ccccc} 
& Specimen & Length $(\mathrm{mm})$ & Height $(\mathrm{mm})$ & \multicolumn{2}{c}{$1 / 2$} & Thickness (mm) \\
GT. Y6301 (Holotype) & 10.0 & 6.2 & - & Right \\
" 6302 & 9.0 & 5.2 & - & $" 1$ \\
" 6304 & 8.9 & 5.8 & 2.0 & $\prime \prime$ \\
" 6309 & 8.0 & 5.7 & 1.8 & $\prime \prime$
\end{tabular}




$\begin{array}{rrrrc}\text { " } 6323 \text { (Paratype) } & 8.8 & 5.8 & - & \text { " } \\ \text { GT. K6341 } & 9.5 & 6.0 & - & " \text { " } \\ \text { GT. Y6305 (Paratype) } & 8.8 & 5.7 & 1.8 & \text { Left } \\ \text { " } 6306 & 8.0 & 5.5 & - & \prime \prime \\ \text { " } 6308 & 9.0 & 5.8 & 2.0 & \prime \prime \\ \text { " } 6311 & 8.7 & 4.8 & - & \prime \prime\end{array}$

Diagnosis.-The important characters of this species have been given above in the generic diagnosis. The valves are moderately inflated, elongated subtrigonal and resemble a minute Trigonia (s.s.) in external appearance. The concentric sculpture consists of moderately wide ribs separated by narrow interspaces. The umbones are prosogyrate, strongly inflated in comparison with the rest of the valve. The peculiar features of the hinge as described in the generic diagnosis, is characteristic of this species.

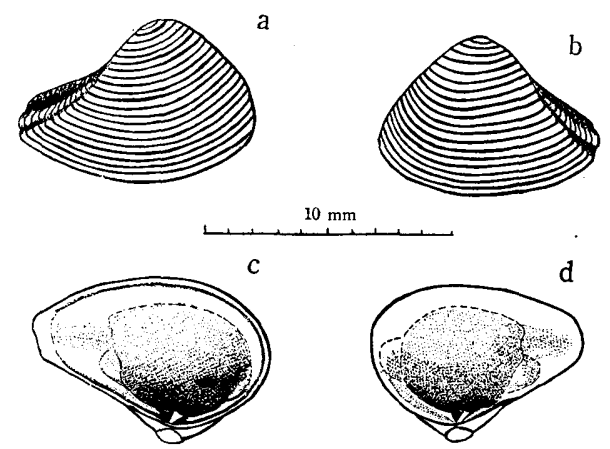

Fig. 1. Pulsidis nagatoensis n. gen. \& n. sp. All the text-figures in this paper are the synthetic figures constructed on the basis of the holotype and paratypes. They may show the characteristics of each species. Y. OTA Del.

Remarks.-There are some ontogenetic changes in the outline and inflation of the shell. The outline, for example, is generally subelliptical and not rostrated to the posterior in the younger stage. In the adult stage, however, the outline is rounded, inflated and fairly rostrated to the posterior.

Comparisons.-HASE (1960) established Corbula matsumotoi on the basis of the specimens (Holotype, GK.* H6084, Pl. 39, figs. 5a-d and Paratypes, GK. H6085, 6086 and 6087, Pl. 39, figs. 6-8) from the Lower Cretaceous Kawaguchi Formation at Sakayori-agaru, Kawamata-mura, Yatsushiro-gun, Kumamoto Pref., and he, furthermore, regarded the Yoshimo specimens as related to $C$. matsumotoi. The specimens from Yoshimo mentioned by HASE is, however, identical with the present species, which is evidently distinguishable from the redefined C. matsumotoi, i.e. Eoursivivas matsumotoi, n. gen., to be described below (see p. 156), in the size, the inflations of the umbonal and median areas, the thickness of shell, the surface ornamentation and the hinge structure.

The present new species is similar to Parmicorbula neaeroides (BLANCKEN-

* GK=Department of Geology, Kyushu University. 
HORN), from the Aptian of Lebanon, in the outline and ornamentation, but distinguished from that species in having non-rectangular siphonal plate in the posterior part of the shell. In the hinge structure this new species is fairly similar to Caryocorbula alabamiensis LEA (HARRIS, 1919, p. 185, pl. 56, figs. 2026), the type of Caryocorbula, from the Eocene of North America, but it is distinguishable from that American species by the absence of the median ridge on the chondrophore, and the rounded shape and the regular concentric ribs.

Occurrence.-Very common in the black fine sandstone and shale of the Lower Cretaceous (probably Lower Neocomian) Yoshimo Formation on the coastal region of Yoshimo in Shimonoseki city, Yamaguchi Pref. Probably identical examples are also common in the sandy shale of the Lower Cretaceous (Lower Neocomian) Kawaguchi Formation at Tanoura, Ashikita-gun, Kumamoto Prefecture, but rather rare in the black shale of the same Formation at Fukami in Yatsushiro-gun, Kumamoto Prefecture.

Pulsidis okadai, sp. nov.

Pl. 20, figs. 15-24; Text-fig. 2.

Material.-Holotype, GT. M6365, a right inner mould (Pl. 20, fig. 15). Paratypes, GT. M6377, a right external mould (PI. 20, fig. 23) and GT. M6380 and 6382, right inner moulds (Pl. 20, figs. 17, 20). All the above types were collected by me from the Lower Formation of the Mifune Group at a locality about $300 \mathrm{~m}$ east of Kawachida, Masuki-machi, Kamimasuki-gun, Kumamoto Prefecture.

Diagnosis.-The shell is of moderate size, subelliptical to elongated subtrigonal in outline. The umbones are posteriorly situated approximately halfway between the posterior two-thirds and the mid-length of the shell. The valves are unequal; the right valve is larger than the left, protruding its posterior part beyond the left. Both valves are rostrated with an obtuse ridge extending from the umbo to the postero-ventral margin. The posterior margin of the right valve is generally truncated.

The surface is ornamented with concentric growth-lines. In the late growthstage some strong striae may be seen at irregular intervals in addition to the growth-lines. The internal margin of the right valve is grooved for the reception of the edge of the left. The right cardinal tooth is subtrigonal and declines to the anterior in parallel with the anterodorsal margin; the adjoining resilial socket is deep and broad. The left valve has a relatively broad, subtrigonal chondrophore with a shallow groove on the median area. The anterior cardinal socket is subtriangular, somewhat open above.

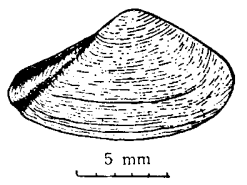

Fig. 2. Pulsidis okadai n. sp. 
The muscle scars are inconspicuous, and the pallial line is simple, with a scarcely defined sinus.

\begin{tabular}{|c|c|c|c|c|c|}
\hline & Specimen & Length $(\mathrm{mm})$ & Height (mm) & \multicolumn{2}{|c|}{ 1/2 Thickness (mm) } \\
\hline GT. & M6351 & 11.0 & 7.0 & - & Right \\
\hline$\prime \prime$ & 6358 & 8.0 & 4.0 & - & "I \\
\hline 11 & 6362 & 15.2 & 7.0 & - & $\prime \prime$ \\
\hline 11 & 6365 (Holotype) & 14.8 & 7.0 & - & $\prime \prime$ \\
\hline$\prime \prime$ & 6366 & 15.0 & 7.0 & - & $\prime \prime$ \\
\hline$\prime \prime$ & 6368 & 13.0 & 7.0 & 2.2 & "1 \\
\hline$\prime \prime$ & 6372 & 7.5 & 4.6 & 1.8 & $\prime \prime$ \\
\hline "I & 6379 & 8.0 & 5.0 & - & Left \\
\hline$\prime \prime$ & 6381 & 8.5 & 5.0 & 一 & "1 \\
\hline
\end{tabular}

Remarks.-Many specimens occur in the black fine sandstone and shale of the Lower Formation of Mifune Group, but a great number of specimens are more or less deformed. There are some variations in the degree of convexity of the postero-dorsal margin and in the position of umbo. In many specimens the postero-dorsal margin is nearly straight or slightly sinuated behind the beak, but in some specimens it is considerably sinuous and the umbo is fairly protruded beyond the hinge margin. The position of the umbo varies from median to two-thirds from the anterior extremity of shell.

Comparisons.-Pulsidis nagatoensis, from the Lower Cretaceous Yoshimo Formation, is somewhat similar to this species in the posteriorly rostrated form, but this differs from it in its longer and slender outline and much finer surface ornamentation of the shell. $P$. okadai is probably derived from $P$. nagatoensis because the shell of the young stage of $P$. okadai is very similar to $P$. nagatoensis. Eoursivivas matsumotoi (HASE), from the Lower Cretaceous Kawaguchi Formation, is apparently similar to the present species in the outline and ornamentation, but the two species differ from each other in the size and hinge structure. Corbula (Caryocorbula) horrii (GABB, 1864) (STEWART, 1930, p. 287, Pl. 12, figs. 4, 5), from the Eocene Tejón formation of California, is fairly similar to this species in the outline and ornamentation, but that American species has a low ridge on the posteriorly rostrated area and a median ridge on the chondrophore.

Occurrence.-Very common in the black fine sandstone and shale of the Lower Formation of the Mifune Group at Kawachida, Masuki-machi, Kamimasuki-gun, Kumamoto Prefecture. The Age of the Mifune Group ranges, according to Matsumoto (1963, p. 109, 120) from Upper Albian to Turonian. The fossiliferous Lower Formation is probably Cenomanian but may include Upper Albian.

\section{Pulsidis higoensis (MATsumoto)}

Pl. 21, figs. 13-17; Text-fig. 3.

1938. Aloidis (Caryocorbula) higoensis Matsumoto, Jour. Geol. Soc. Japan, Vol. 45. (532) p. 19, pl. 2, fig. 8, text-fig. 9.

Lectotype.-Of the syntypes of MAтsumoтo, which are now preserved in the 
University of Tokyo, one of the illustrated specimens, Matsumoto, 1938, pl. 2, fig. 8, from the Gosyonoura Group in Kumamoto Prefecture, is designated here as lectotype.

Material.-I have seen five right inner moulds from the Gosyonoura Group and a greater number of specimens from the Yatsushiro Formation. The selected examples are as follows; GT. G63100-63104, all from the Member IId of Middle Formation of the Gosyonoura Group, and GT. Y63105-63111, all from the Yatsushiro Formation at a locality about $2 \mathrm{~km}$ south of Miyaji-machi, Yatsushiro city.

\section{Measurements.-}

\begin{tabular}{cr}
\multicolumn{2}{r}{ Specimen } \\
GT. \\
" 633100 \\
" & 63102 \\
GT. & 63104 \\
GT. Y63105 \\
" & 63106 \\
" & 63107 \\
" & 63109 \\
" & 63110 \\
" & 63111 \\
" & 63108
\end{tabular}

Length $(\mathrm{mm})$
12.5
12.0
15.5
11.8
10.0
11.0
4.0
11.8
13.5
10.8

Height $(\mathrm{mm})$
9.0
7.5
10.4
9.0
7.0
7.2
3.0
9.0
9.0
8.0

$\begin{array}{cc}1 / 2 & \text { Thickness (mm) } \\ 2.3 & \text { Right } \\ 2.8 & \prime \prime \\ 4.0 & \prime \prime \\ 1.6 & \prime \prime \\ 2.8 & \prime \prime \\ 2.2 & \prime \prime \\ - & \prime \prime \\ 2.4 & \prime \prime \\ - & \prime \prime \\ 2.0 & \text { Left }\end{array}$

Diagnosis.-The shell is relatively small and the test is thick; the valves are unequal, the right being larger than the left. Both valves are posteriorly rostrated with an obtuse ridge extending from the umbo to the postero-ventral margin. Antero-dorsal margin is nearly straight or moderately convex, distinctly sloping into the anterior one without forming a marked angle; ventral margin is fairly long, broadly arched, forming an acute angle with the posterior margin, which is short, nearly straight or very weakly curved; postero-dorsal margin is almost as long as the antero-dorsal, usually excavated, forming an obtuse angle with the posterior margin.

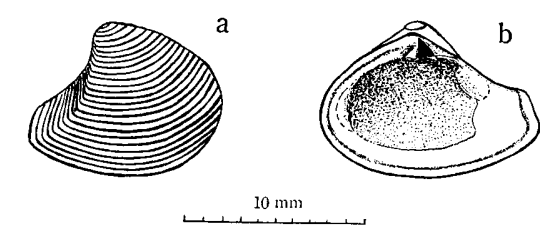

Fig. 3. Pulsidis higoensis (Matsumoto)

Umbo is rather large, prominent, incurved, subcentral; the shell is most inflated on the umbonal area, and gently compressed to the ventral and posterior margins. Surface is ornamented with moderately strong concentric ribs, which are top-flattened and wider than the interspaces between the ribs.

Hinge-plate is rather wide and stout; right valve is provided with a prominent, up-curved, triangular tooth just below the beak, behind which is a triangular, fairly deep socket to receive the chondrophore of the left valve. Both adductor scars are fairly large and subelliptical in outline. Pallial line forms a 
right angle at the postero-ventral corner and is scarcely sinuated.

Remarks.-MAтsumoto (1938, p. 19) described Aloidis (Caryocorbula) higoensis from the Gosyonoura Group, but his description was very brief. As the details of its chondrophore are not distinct, the taxonomic position of this species is obscure. It is probably related to the genus Pulsidis from other characters.

Comparisons.- $P$. nagatoensis from the Lower Neocomian Yoshimo Formation is fairly similar to $P$. higoensis in the outline and surface ornamentation, although the latter has no median ridge and is rather flattened on the posteriorly rostrated area. The present species is somewhat similar to Tenuicorbula tenuis lupina OLsson (1900, p. 235, pl. 14, fig. 10), from the Miocene in Peru, in the ornament and posteriorly rostrated form, but differs from that Peruvian subspecies in the finer sculpture, the absence of the cord-like keel and the hinge structure. It is also similar to $C$. striatula SowERBY, from the Hythe beds of Lower Greensand, in the ornament and outline, although it is distinguished from that British species in having strong posterior carinae and escutcheon.

Occurrence.-Common in the medium to rather coarse-grained arkosic sandstones at various horizons of the Member IId of the Upper Albian-Turonian Gosyonoura Group at Gosyonoura Isl. and in Kumamoto Prefecture. Very common in the black fine sandstone and shale of the Albian Yatsushiro Formation at a locality $2 \mathrm{~km}$ south of Miyaji-machi, Yatsushiro city in the same Prefecture.

\section{Genus Eoursivivas, nov.}

Type-species.-Corbula matsumotoi HASE, 1960.

Generic diagnosis.-The shell is moderately large for the subfamily, fairly thin, elongated subpyriform, and nearly equivalved, the right valve being slightly larger than the left. The umbones are anterior, situated approximately at the one-third from the anterior extremity of the valve. The anterior and median areas of the valve are moderately inflated; posteriorly the valves are narrowed and compressed. The surface of both valves is ornamented with numerous fine, closely set, irregularly roughened, concentric growth-lines and a few gentle concentric undulations. The ventral margin of the right valve is grooved for the reception of the margin of the left.

The right cardinal tooth is moderately heavy, upcurved at the tip; the adjoining resilial socket is triangular and deep. The left valve has a relatively broad subtriangular chondrophore which is, posteriorly, continuous with the dorsal margin of the valve, being separated from it by a shallow groove. The dorsal side of the chondrophore bears a well-developed median ridge. The anterior cardinal socket is trigonal and somewhat opened upward. Muscle scars are relatively prominent, somewhat rugose; the pallial line is simple, with a short and indistinct sinus.

Affinities.-In having the chondrophore in the left valve and the above mentioned hinge-structure, this new genus is certainiy referred to the subfamily 
Caryocorbulinae. In the hinge structure of Eoursivivas matsumotoi is most similar to Ursivivas pyriformis (MEEK, 1871), the type-species of genus Ursivivas, VoKes, 1945, but they are distinguished by the following significant points. The median ridge on the chondrophore of Eoursivivas matsumotoi extends for a longer distance to the beak than of Ursivivas pyriformis. The shape of cardinal socket of the former is rather subtriangular, but that of the latter is rather rounded. The hinge-plate of the former is weak, but that of the latter is stout. The former has no lunule, escutcheon and the groove for the reception of the dorsal margin of the right. Therefore, a new genus is instituted here on the Corbula matsumotoi.

In the hinge feature Eoursivivas is somewhat similar to Caryocorbula alabamiensis LEA, but it has no dorso-lateral ridge on the chondrophore. This genus is also somewhat similar to Parmicorbula neaeroides (BLANCKENHORN), from the Aptian of Lebanon, the type-species of genus Parmicorbula VoKes, 1944, in the outline and hinge structure, but the former can be distinguished from the latter in having no rectangular siphonal plate.

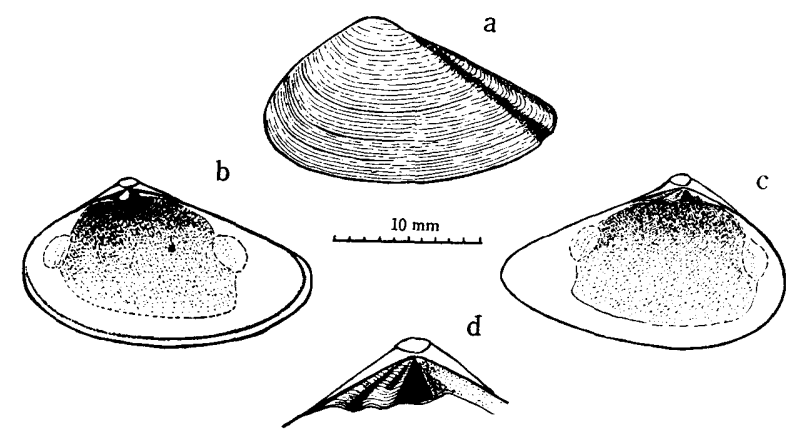

Fig. 4. Eoursivivas matsumotoi (HASE)

\section{Eoursivivas matsumotoi (HASE)}

Pl. 21, figs. 1-11; Text-fig. 4.

1960. Corbula matsumotoi HASE, Jour. Sci. Hiroshima Univ., ser. C, vol. 3, no. 2, p. 322, pl. 39, figs. 5-21; Text-fig. 6 .

Material.-GT. K63050-63070, all topotypes from the Kawaguchi Formation. GT. K63080-63087, from the same formation at Tanoura, Ashikita-gun, Kumamoto Prefecture.

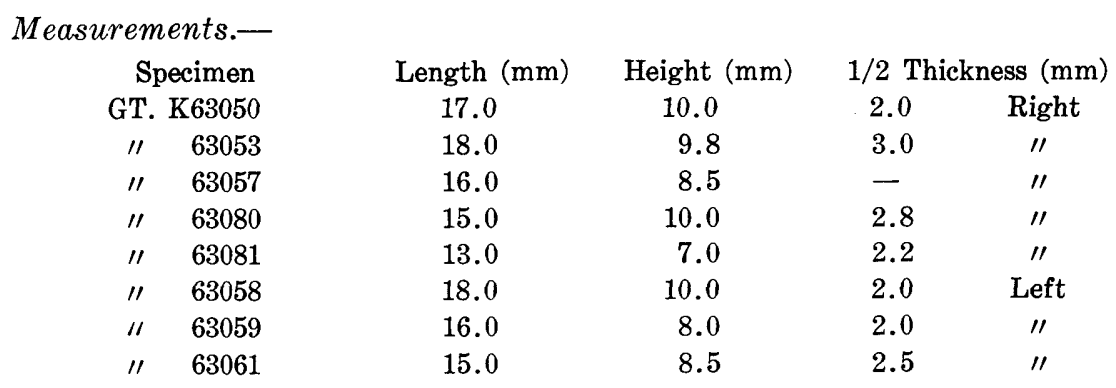


Descriptive remarks. - The important characters of this species have been given in the above generic diagnosis. The shell is most inflated in the umbonal area and gently compressed and narrowed to the ventral and posterior margins. An obtuse ridge extends from the umbo to the postero-ventral corner and the shallow grooves appear on both sides of the ridge. The specimens from the cutting near Tanoura rail-road tunnel are considerably small as compared with the topotypes.

Comparisons.-This species is in no way related to Pulsidis nagatoensis, from the Yoshimo Formation, having distinct differences in the chondrophore, outline, ornamentation and thickness of the shell. It is fairly similar to Pulsidis okadai from the Upper Albian-Turonian Mifune Group in the outline and rostrate form, but it differs from $P$. okadai in the hinge characters and is larger than that species.

Occurrence.-Common in the black shale of the Lower Neocomian Kawaguchi Formation at Sakayori-agaru, Kawamata-mura, Yatsushiro-gun, and at the cutting near the rail-road tunnel, Tanoura-machi, Ashikita-gun, Kumamoto Prefecture.

Genus Nipponicorbula, nov.

Type-species.-Nipponicorbula mifunensis, gen. et sp. nov.

Generic diagnosis.-The shell is relatively small for subfamily, moderately thick, and elongated subtrigonal. In both valves a prominent ridge extends from the umbo to the antero-ventral margin. The valves are unequal, the right being larger than the left. The right valve is sharply rostrated, with a strong cord-like keel extending from the umbo to the postero-ventral margin and another weaker keel extending to the ventral side of the posterior end; the area between the two keels is flattened or more or less convex. The left valve is more or less rostrated but not so posteriorly protruded as the right.

The sculpture is dissimilar between the left and right valves, and furthermore very different between the disc and the posterior rostrated area of the right valve. The disc of the right valve is marked with conspicuously strong cancellate sculpture, but the rostrated area is covered with growth-lines only. The left valve is ornamented with moderately strong concentric ribs and on the median area a few slender radial ribs are added to them.

The interior of the right valve is grooved for the reception of the margins of the left valve. The hinge of the right valve consists of a large triangular cardinal tooth and a resilial pit which lies somewhat dorsad of the cardinal. The hinge of the left valve consists of a cardinal socket and a relatively narrow, moderately elongate chondrophore, which has an elongate groove in parallel with the dorsal margin.

The adductor scars are moderately large but slightly impressed; the pallial line is obscure, and the pallial sinus scarcely defined.

Affinities.-This genus is clearly referable to the subfamily Caryocorbulinae, 
in having a chondrophore on the left valve. The distinct characteristics of this genus are the discrepancy of sculpture between both valves; the distinctly cancellate sculpture is developed on the right valve, which has a strong cord-like keel on the posterior rostrated area, while the concentric ribs are predominant over the poorly developed radial ribs on the left valve. Genus Parmicorbula VoKes, 1944, with the type-species: P. neaeroides (BLANCKENHORN), from the Aptian of Lebanon, is more or less similar to this new genus in the hinge structure, but in this genus the siphonal plate is not rectangular and the surface ornamentation has no cancellation. Another genus Corbulomina Vokes, 1945, with the type-species $C$. nuciformis VoKEs, 1945, from the Aptian of Lebanon, can be easily distinguished from Nipponicorbula in the outline and surface ornamentation. This genus can be also easily distinguished from the hitherto known Cretaceous genera from the Eastern Asia by the characteristic surface ornamentation and hinge structure. This genus is very unique in both the fossil and living Corbulidae in having the discrepancy of sculpture between both valves and especially the prominent cancellated sculpture on the right valve.

Nipponicorbula mifunensis, sp. nov.

Pl. 21, figs. 18-27; Text-fig. 5.

Material.-Holotype, GT. M63001, the right valve (Pl. 21, fig. 18). Paratypes, GT. M63002, the right valve (Pl. 21, fig. 19); GT. M63020, the left valve (Pl. 21, fig. 20) and GT. M63019, the left inner mould (Pl. 21, fig. 22). All the above types were collected by me from the Lower Formation of the Mifune Group st a locality $500 \mathrm{~m}$ south of Asanoyabu, Mifune-machi, Kamimasuki-gun, Kumamoto Prefecture.

Diagnosis.-Shell is relatively small, elongated subtrigonal in outline, and the length is about one and a half times as large as the height. Umbo is situated slightly anterior to the mid-length of the shell, moderately large, prominent and prosogyrate, only a little more inflated in comparison with the rest of the valve. Valves are unequal, the right valve being larger and more rostral than the left. Test is very thick. Anterodorsal and posterodorsal margins form an angle of $130^{\circ}$ to $140^{\circ}$ below the beak; postero-dorsal margin is nearly straight, and distinctly slopes down, forming an acute angle with the ventral margin; ventral margin fairly long, broadly arched, passing insensibly into the short and rounded anterior margin; antero-dorsal margin shorter than the postero-dorsal, slightly convex, distinctly sloping down to the anterior one without forming a marked angle. The prominent ridges extend from the umbo towards both the anteroand postero-ventral corners; anterior one is blunt and higher than the posterior one. The posterior one is doubled, consisting of a prominent posterior cord-like keel along the postero-dorsal margin and the other obtuse ridge which is situated along the posterior margin of the disc and separated from the cord-like one by a flattened, narrow area.

Surface sculpture is discrepant between the left and right valves, and 
furthermore discrepant between the disc and the posterior rostrated area on the right valve. The disc of the right valve is ornamented with the cancellation which consists of roundly topped radial and concentric ribs of equal strength. The ribs are wider than the interspaces. The posterior rostrated area is sculptured with the fine growth-lines only. The sculpture of the left valve consists of the moderately strong concentric ribs, with several weak radial ribs on the median area.

The hinge structure is as described in the diagnosis of the genus. Pallial line forms a right angle at the postero-ventral corner and is scarcely sinuated.

Measurements.-

\begin{tabular}{rcccc} 
Specimen & Length $(\mathrm{mm})$ & Height $(\mathrm{mm})$ & \multicolumn{2}{c}{$1 / 2$ Thickness $(\mathrm{mm})$} \\
GT. M63001 & 10.0 & 5.0 & 2.0 & Right \\
63002 & 8.0 & 5.0 & 1.8 & $\prime \prime$ \\
63005 & 9.8 & 5.6 & 1.8 & $\prime \prime$ \\
63006 & 10.5 & 6.0 & 3.0 & $\prime \prime$ \\
63008 & 8.0 & 5.0 & 2.8 & $\prime \prime$ \\
63009 & 7.0 & 4.3 & - & $\prime \prime$ \\
63025 & 7.0 & 3.5 & 1.7 & $\prime \prime$ \\
63020 & 5.0 & 3.0 & 1.7 & Left \\
63021 & 10.6 & 6.0 & 3.0 & $\prime \prime$ \\
63022 & 5.0 & 3.5 & - & $\prime \prime$
\end{tabular}

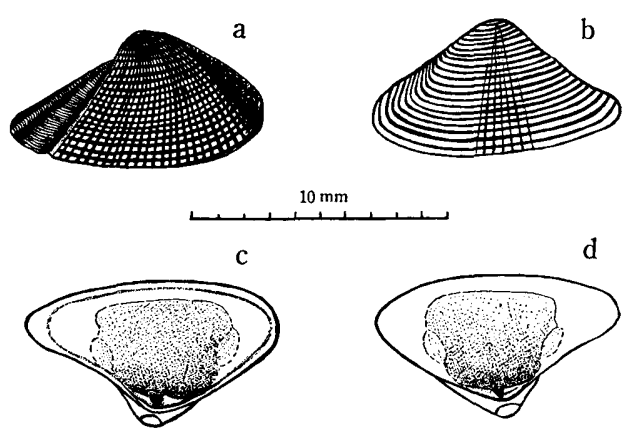

Fig. 5. Nipponicorbula mifunensis n. gen. \& n. sp.

Comparisons.-Bothrocorbula radiatula DALL, 1898, from the Upper Oligocene of Oak Grove in Florida, is somewhat similar to this species in the outline and radial ribs. In $B$. radiatula the radial threads are only developed on the interspaces between the concenrtic ribs. More or less similar cancellate sculpture appears in Cuneocorbula sericea DALL (1900, p. 848, pl. 36, fig. 8), from the Oligocene marl of Bowden, Jamaica and the Pliocene(?) of Port Limon, Costa Rica, but that West Indies species differs from the present one in the fine and closely-set ribs similarly developed on both valves. C. aldrichi MEYER (SHIMER and SHRock, 1944, p. 431, pl. 172, figs. 13, 14), from the Eocene of North America, is somewhat similar to this in the presence of a cancellate sculpture, but that of $C$. aldrichi is confined to the umbonal area.

Occurrence.-Common in the black fine sandstone and shale of the Lower 
Formation of the Mifune Group at a locality $500 \mathrm{~m}$ south of Asanoyabu, Mifunemachi, Kamimasuki-gun, Kumamoto Prefecture. The age of the formation is probably somewhere in the Upper Albian and Cenomanian.

\section{Summary of Results}

As summarized results I list here the species of the Corbulidae from the Cretaceous of Kyushu and Chugoku which have been described above, with their stratigraphic occurrence:

(1) Pulsidis nagatoensis n. gen. \& n. sp., from the Lower Neocomian Yoshimo Formation in Yamaguchi Prefecture; also P. sp. cf. $P$. nagatoensis, from the Lower Neocomian Kawaguchi Formation, Kumamoto Prefecture.

(2) Pulsidis okadai n. sp., from the Upper Albian-Turonian Mifune Group in Kumamoto Prefecture.

(3) Pulsidis higoensis (MAтsumoto), from the Upper Albian-Turonian Gosyonoura Group and the Albian Yatsushiro Formation in Kumamoto Prefecture.

(4) Eoursivivas matsumotoi (HASE) n. gen., from the Lower Neocomian Kawaguchi Formation in Kumamoto Prefecture.

(5) Nipponicorbula mifunensis n. gen. \& n. sp., from the Upper AlbianTuronian Mifune Group in Kumamoto Prefecture.

\section{Locality Guide}

Tanoura-machi, Ashikita-gun, Kumamoto Prefecture (熊本県莘北郡田ノ浦町)

Kawachida, Masuki-machi, Kamimasuki-gun, Kumamoto Prefecture（熊本県上益城郡益城町川内田）

Asanoyabu, Mifune-machi, Kamimasuki-gun, Kumamoto Prefecture (熊本県上益城郡御船町浅藪)

Sakayori-agaru, Kawamata-mura, Yatsushiro-gun, Kumamoto Prefecture (熊本県八代郡川俣村坂ヨリ上ル) Hongo, Gosyonoura-mura, Amakusa-gun, Kumamoto Prefecture (熊本県天草郡御所浦村本郷)

Tani, Miyaji-machi, Yatsushiro city, Kumamoto Prefecture（熊本県八代市宮地町谷）

Fukami, Sakamoto-machi, Yatsushiro-gun, Kumamoto Prefecture (熊本県八代郡坂本町深水)

Yoshimo, Shimonoseki city, Yamaguchi Prefecture (山口県下関市吉母)

$\begin{array}{cc}\text { East Long. } & \text { North Lat. } \\ 130^{\circ} 20^{\prime} & 32^{\circ} 22^{\prime} \\ 130^{\circ} 52^{\prime} & 32^{\circ} 47^{\prime} \\ 130^{\circ} 54^{\prime} & 32^{\circ} 46^{\prime} \\ 130^{\circ} 46^{\prime} & 32^{\circ} 31^{\prime} \\ 130^{\circ} 21^{\prime} & 32^{\circ} 20^{\prime} \\ 130^{\circ} 39^{\prime} & 32^{\circ} 29^{\prime} \\ 130^{\circ} 40^{\prime} & 32^{\circ} 28^{\prime} \\ 130^{\circ} 52^{\prime} & 34^{\circ} 05^{\prime}\end{array}$

\section{References Cited}

DALL, W. Healey (1898): Contributions to the Tertiary fauna of Florida, with especial reference to the Silex Beds of Tampa and the Pliocene Beds of the Caloosahatchie River. Wagner Free Inst. Sci., 3, (4), 571-947, 23-35 pls. 
HASE, Akira (1960): The Late Mesozoic Formations and their Molluscan Fossils in West Chugoku and North Kyushu, Japan. Jour. Sci. Hiroshima Univ., Ser. C, 3, (2), 283$338,35-39$ pls.

Matsumoto, Tatsuro (1938): Geology of Gosyonoura Islands, Amakusa, with Special Reference to the Cretaceous Stratigraphy (in Japanese, with Preliminary Notes on Some of the More Important Fossils among the Gosyonoura Fauna in English). Jour. Geol. Soc. Japan, 45, (532), 1-47, 1-3 pls.

- (1963): The Cretaceous. In TakaI, Fuyuji, T. Matsumoto and R. ToriYama [Editors] (1963): Geology of Japan, 99-128. Univ. Tokyo Press., Tokyo.

OLsson, Axel A. (1932): Contributions to the Tertiary paleontology of northern Peru: Part 5, the Peruvian Miocene. Bull. Amer. Paleont., 19, (68), 1-272, 1-24 pls.

Shimer, W. Hervey \& SHROcK, R. Robert (1944): Index fossils of North America, p. 431, pl. 172, figs. 13, 14.

STewart, R. Bentley (1930): Gabb's California Cretaceous and Tertiary type Lamellibranchs. Acad. Nat. Sci. Philadelphia, Special Publ., 3, 1-314, 1-17 pls.

VoKEs, Harold E. (1941): Geological observations in the Lebanon Mountains of western Asia. Bull. Geol. Soc. Amer. 52, 1715-1732, 3 figs.

(1945): Supraspecific Groups of the Pelecypod Family Corbulidae, Bull. Amer. Mus. Nat. History, 86, (1), 1-32, 1-4 pls.

Woods, Henry (1908): A monograph of the Cretaceous Lamellibranchia of England, 2, (5). Palaeontogr. Soc. London, 1908, 181-216, 28-34 pls. 
Yoshihisa OTA

On some Cretaceous Corbulids from Japan

\section{Plates $20-21$}


Plate 20 


\section{Explanation of Plate 20}

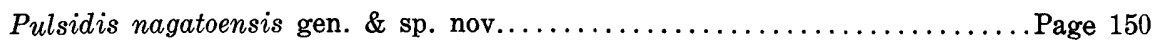

Fig. 1. Right inner mould; Holotype: GT. Y6301; Loc. west coast of Yoshimo, Shimonoseki city, Yamaguchi Pref.; Yoshimo Formation. $(\times 4.2)$

Figs. 2, 3. Right inner moulds; GT. Y6302 and 6334; Loc. and Form. do. $(\times 2.8)$

Fig. 4. Right external mould; Paratype: GT. Y6314; Loc. and Form. do. $(\times 4.0)$

Figs. 5a, 5b. Right inner moulds, showing the hinge character; Paratype: GT. Y6323; Loc. and Form. do. $(\times 4.2)$

Fig. 6. Left inner mould; GT. Y6311; Loc. and Form. do. $(\times 3.0)$

Fig. 7. Left inner mould, showing the hinge character; Paratype: GT. Y6303; Loc. and Form. do. $(\times 4.2)$

Fig. 8. Right inner mould, showing the hinge character; GT. Y6320; Loc. and Form. do. $(\times 3.4)$

Fig. 9. Right inner mould, showing the hinge character; Paratype: GT. Y6322; Loc. and Form. do. $(\times 4.2)$

Fig. 10. Right inner mould; GT. Y6307; Loc. and Form. do. $(\times 4.2)$

Fig. 11. Right inner mould; GT. Y6339; Loc. Fukami, Sakamoto-machi, Yatsushiro-gun, Kumamoto Pref.; Kawaguchi Formation. $(\times 3.2)$

Fig. 12. Left inner mould; GT. Y6340; Loc. west coast of Yoshimo; Yoshimo Formation. $(\times 3.8)$

Fig. 13. Right inner mould; GT. K6341; Loc. road side cutting at Tanoura railroad tunnel, Tanoura-machi, Ashikita-gun, Kumamoto Pref.; Kawaguchi Formation. $(\times 3.2)$

Fig. 14. Left external mould; Paratype: GT. Y6316; Loc. Yoshimo, Shimonoseki city; Yoshimo Formation. $(\times 3.2)$

Fig. 25. Showing the occurrence of $P$. nagatoensis; Loc. and Form. do. $(\times 2.0)$

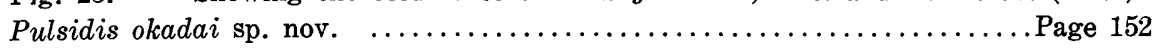

Fig. 15. Right inner mould; Holotype: GT. M6365; Loc. Kawachida, Masuki-machi, Kamimasuki-gun, Kumamoto Pref.; Mifune Group. $(\times 2.5)$

Figs. 16, 19. Right inner moulds; Paratypes: GT. M6380 and 6382; Loc. and Form. do.

Figs. 17, 18, 20 and 21. Right inner moulds; GT. M6368, 6358. 6366 and 6370; Loc. and Form. do.

Fig. 22. Right external mould; Paratype: GT. M6377; Loc. and Form. do.

Figs. 23, 24. Right inner moulds; GT. M6351 and 6367; Loc. and Form. do. 
Mem. Fac. Sci., Kyushu Univ., Ser. D, Geology, Vol. XV

Plate 20

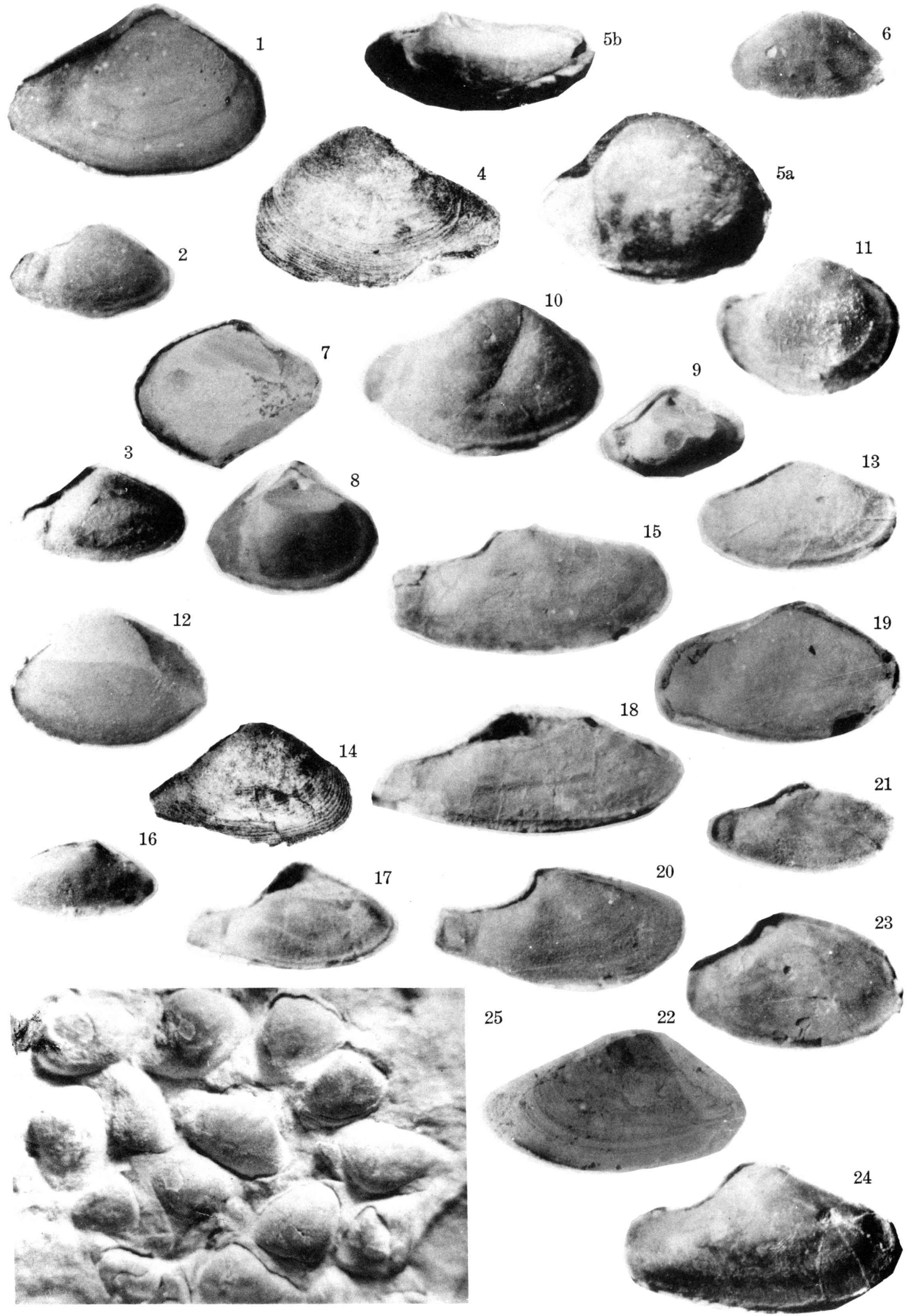

Y. Ота: On Some Cretaceous Corbulids from Japan 
Plate 21 


\section{Explanation of Plate 21}

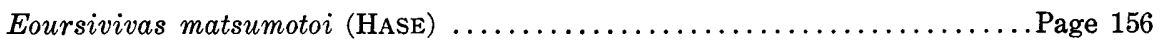

Figs. 1, 2. Right inner moulds; GT. K63050 and 63054; Loc. Sakayori-agaru, Kawamata-mura, Yatsushiro-gun, Kumamoto Pref.; Kawaguchi Formation $(\times 2.8)$

Figs. 3-6. Left inner moulds; GT. K63061, 63059, 63058 and 63062; Loc. and Form. do. $(\times 2.6)$

Fig. 7. Right external mould; GT. K63067; Loc. and Form. do. $(\times 2.7)$

Fig. 8. Left external mould; GT. K63068; Loc. and Form. do. $(\times 3.0)$

Fig. 9. Left inner mould, showing the hinge character; GT. K63064; Loc. and Form. do. $(\times 2.4)$

Figs. 10-11. Right inner moulds; GT. K63053, 63057 and 63052; Loc. and Form. do. $(\times 2.4)$

Pulsidis higoensis (Matsumoto)................................... 153

Figs. 13, 16. Right inner moulds; GT. G63104, 63102 and 63100; west of Gosyonouramura, Amakusa-gun, Kumamoto Pref.; Gosyonoura Group. $(\times 3.4)$

Fig. 14. Left inner mould; GT. Y63110; Loc. Miyaji-machi, Yatsushiro city; Yatsushiro Formation. $(\times 2.4)$

Fig. 15. Right external mould; GT. Y63114; Loc. and Form. do. $(\times 3.4)$

Fig. 17. Right inner mould; GT. Y63111; Loc. and Form. do. $(\times 3.4)$

Nipponicorbula mifunensis gen. \& sp. nov. ............................ 158

Fig. 18. Right valve; Holotype: GT. M63001; Loc. Asanoyabu, Kamimasuki-gun, Kumamoto Pref.; Mifune Group. $(\times 5.0)$

Fig. 19. Right valve; Paratype: GT. M63002; Loc. and Form. do. $(\times 5.0)$

Fig. 20. Left valve; Paratype: GT. M63020; Loc. and Form. do. $(\times 4.6)$

Fig. 21. Left valve; GT. M63021; Loc. and Form. do. $(\times 4.4)$

Fig. 22. Left inner mould, showing the hinge character; Paratype: GT. M63019; Loc. and Form. do. $(\times 6.4)$

Figs. 23, 24. Right inner moulds; GT. M63026 and 63009; Loc. and Form. do. $(\times 4.4)$

Fig. 25. Right valve; GT. M63015; Loc. and Form. do. $(\times 4.4)$

Figs. 26, 27. Right valves, showing the cancellate sculpture; GT. M63012 and 63030; Loc. and Form. do. $(\times 6.0)$ 


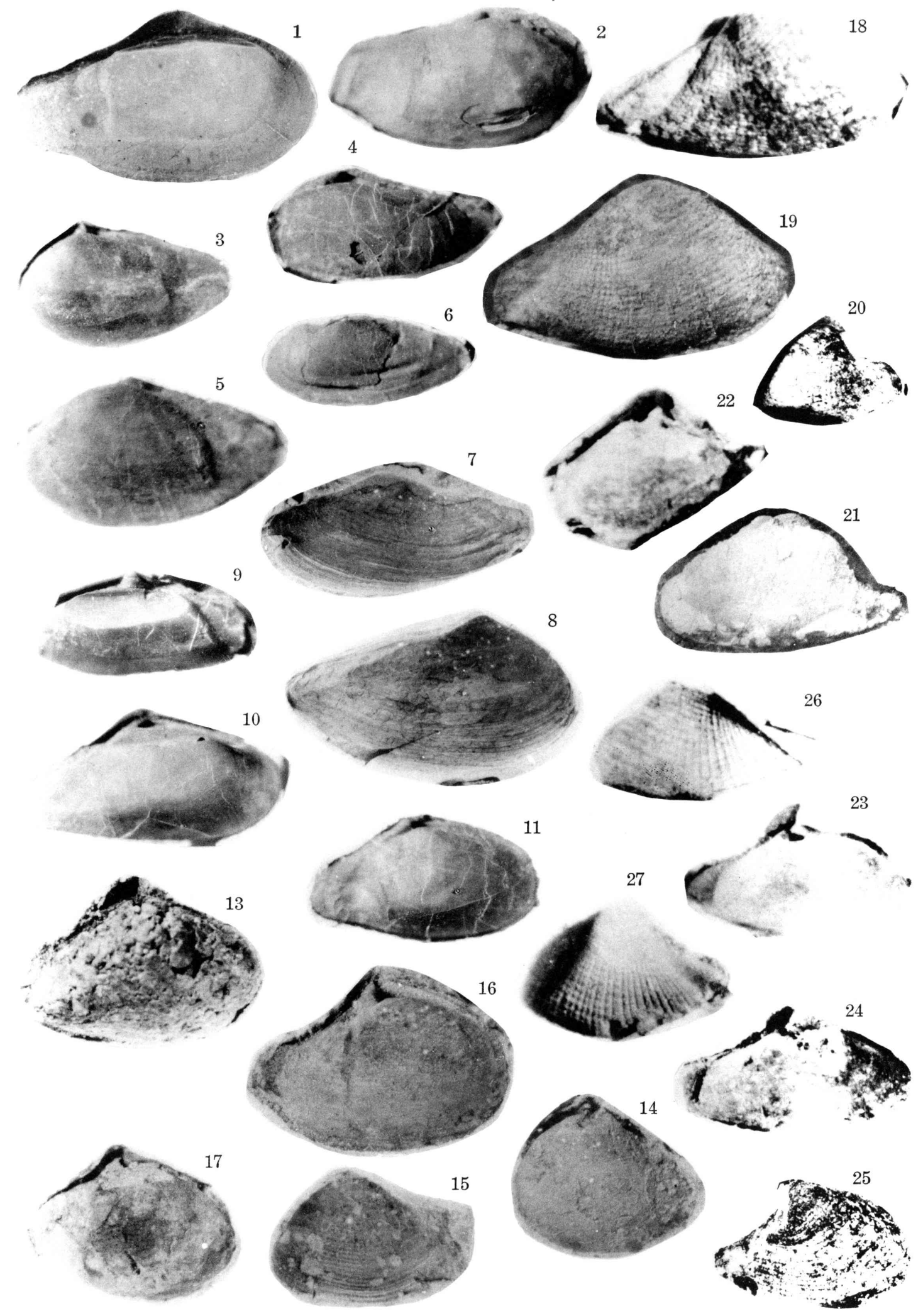

Y. Ота: On Some Cretaceous Corbulids from Japan 